\title{
Nondestructive Evaluation of Wall Thinning in Pipes \\ by Time Domain Measurement of Microwaves
}

\section{○近藤 佑輔（名大） 正 細井 厚志（名大） 正 巨 陽（名大）}

Yusuke KONDO, Nagoya University, Furo-cho, Chikusa-ku, Nagoya Atsushi HOSOI, Nagoya University, Furo-cho, Chikusa-ku, Nagoya Yang JU, Nagoya University, Furo-cho, Chikusa-ku, Nagoya

Key Words: Microwave, Nondestructive evaluation, Wall Thinning, Pipe, Time domain

\section{1. 緒言}

近年, 配管減肉に起因した事故がたびたび報告されている. 安全・安心な社会を構築するため, 高経年エネルギー機器の 状態監視技術の更なる高度化は必要不可欠である. その中で も，配管の状態監視技術の実現は，そのニーズが非常に高い にもかかわらず，いまだ確立されていない状況にある.

これまで円型導波管内マイクロ波の伝播原理に基づき，マ イクロ波を配管内に伝播させ，マイクロ波の波長が配管の内 径に依存する特徵を利用して計測を行った。この手法は，減 肉量に伴い変化する共振周波数を測定することにより, 広範 囲，高速かつ簡便に減肉量を定量評価できる。しかし，この 手法では，減肉の位置を特定することは難しい，そこで，本 研究では，時間領域測定法により減肉位置を評価することを 目的とした。

\section{2. 測定原理}

時間領域測定とは，ある周波数領域におけるマイクロ波信 号の応答を時間領域に変換する手法であり，マイクロ波信号 の波形の変化からマイク口波が反射された位置を特定する ことができる. 周波数領域として得た結果に逆フ一リ工変換 を適用することで，マイク口波が欠陥や端部で反射した時間 を測定することができる. 配管内径が変化する箇所では，特 性インピーダンスが変化し，マイクロ波が反射される，その 反射波を検知することによって減肉の位置を特定すること が可能となる.

\section{3. 実験方法}

3. 1 実験装置 Fig. 1 はマイクロ波による配管減肉測定 システム写真を示している。本実験では, 長さ $900 \mathrm{~mm}$, 内 径 $17 \mathrm{~mm}$, 肉厚 $1 \mathrm{~mm}$ の軸対称の直線銅配管を用いた。配管 の一端は，マイクロ波同軸ケーブルセンサと接続され，もう 一端は異なる減肉を導入するために, 減肉ジョイントと接続 されている. Table 1 に各ジョイントの減肉条件を示す.さら に，マイクロ波信号の反射によって配管端部の位置を確認す るために，脱着可能な金属の短絡キャップを装着し，配管端 部で短絡端を形成した. Fig. 2 に配管のモデル図を示し, Fig. 3 に減肉ジョイントおよび短絡キャップの写真を示す.

\section{2 測定条件 5 種類の減肉ジョイントを用い, 配管端} 部に短絡キャップを装着し, 短絡端を形成させた状態で実験 を行った. 配管のキャップ側の端部及び減肉部によるマイク 口波の反射波を検出し, 測定結果より減肉位置の特定と減肉 量について検討した。 マイクロ波の掃引周波数は 10.5 40 $\mathrm{GHz}$ とし, 逆フーリエ変換を行うことで時間領域測定を行っ た.

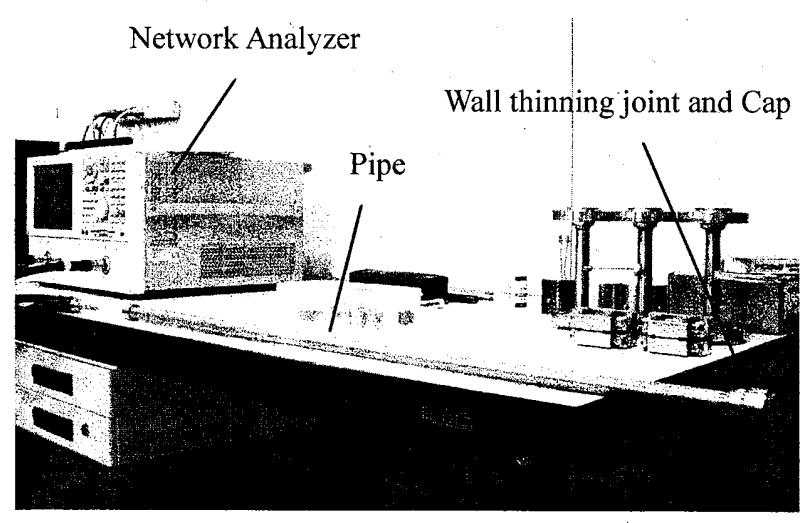

Fig. 1. Photograph of wall thinning measurement system by microwaves.

Table 1. Conditions of wall thinning joints.

\begin{tabular}{c|c|c|c|c}
\hline $\begin{array}{c}\text { Thickness } \\
\text { reduction [\%] }\end{array}$ & $\begin{array}{c}\text { Wall thickness } \\
{[\mathrm{mm}]}\end{array}$ & $\begin{array}{c}\text { inside diameter } \\
{[\mathrm{mm}]}\end{array}$ & $\begin{array}{c}\text { Length } \\
{[\mathrm{mm}]}\end{array}$ & $\begin{array}{c}\text { Wall thinning } \\
\text { Volume }\left[\mathrm{mm}^{3}\right]\end{array}$ \\
\hline 3 & 0.97 & 17.06 & 17 & 27.29 \\
\hline 20 & 0.8 & 17.4 & 17 & 183.72 \\
\hline 40 & 0.6 & 17.8 & 17 & 371.71 \\
\hline 60 & 0.4 & 18.2 & 17 & 563.98 \\
\hline 80 & 0.2 & 18.4 & 17 & 760.52 \\
\hline
\end{tabular}

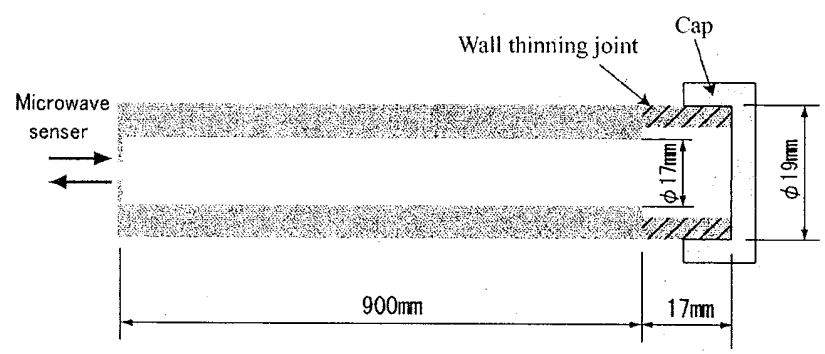

Fig. 2.Model of a pipe with a wall thinning joint and a cap.

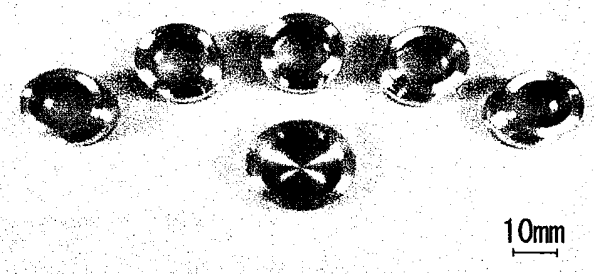

Fig: 3. Photograph of wall thinning joints and a cap. 


\section{4. マイクロ波時間領域測定結果}

Fig. 4 は端部に減肉ジョイントを取り付けずキャップのみ を装着した $900 \mathrm{~mm}$ 配管におけるマイクロ波信号の反射係数 の振幅と掃引したマイク口波の反射時間の関係を示す. Fig. 5 は Fig. 4 の丸で囲われている $7 \times 10^{-9} \sim 9 \times 10^{-9} \mathrm{sec}$ の部分を 拡大した波形である. Fig. 6 及び Fig. 7 は $900 \mathrm{~mm}$ 配管にそれ ぞれ 3\%，40\%の減肉ジョイントとキャップを装着し，時間 領域測定を行った結果を示す. Fig. 4 より配管のセンサー側 端部と減肉ジョイント側端部の反射による波形には振幅が 大きい部分があり，反射のピークはそれぞれ最大ピークの $0.372 \times 10^{-9} \mathrm{sec}$ と $8.09 \times 10^{-9} \mathrm{sec}$ となっている.この閒のマイ クロ波の伝播距離は $1800 \mathrm{~mm}$ であるため，今回の配管の内 径, 伝播モードによるマイクロ波の伝播速度は $2.33 \times 10^{8} \mathrm{~m} / \mathrm{s}$ となる.また, Fig. 5 の丸で囲まれている三つのピークは 2.33 $\times 10^{8} \mathrm{~m} / \mathrm{s}$ で伝播しているマイクロ波が配管端部により反射 されて現れたピークであり，そのときの時間をグラフ上に記 入しておく. 本実験でのマイク口波の伝播速度での減肉キャ ップ $17 \mathrm{~mm}$ を伝播するのに要する時間は $0.146 \times 10^{-9} \mathrm{sec}$ とな り，Fig. 6 の丸で囲まれている部分は Fig. 5 の丸で囲まれて いる部分よりそれぞれ約 $0.15 \times 10^{-9} \mathrm{sec}$ 遅れていることから 減肉キャップの端部の反射によるピークであると推定され る。四角で囲まれている部分はFig. 5 における丸で囲まれて いるピークとほぼ同じ時間となっているため, 約 $900 \mathrm{~mm}$ 地 点による反射を示していることがわかる，従って，四角で囲 まれている部分が減肉部の反射によるピークを示している と考えられ，その反射波には減肉の情報が含まれている. Fig. 7 は同様に丸で囲まれている部分が短絡キャップの端部，四 角で囲まれている部分が減肉部の反射によるピークを示し ている. Fig. 6 及び Fig. 7, その他の減肉ジョイントを取り付 けた場合の結果はほぼ同様の結果となった。

Fig. 8 は Fig. 6 及び Fig. 7, その他の減肉ジョイントを取り 付けた場合の $7.95 \times 10^{-9} \mathrm{sec}$ 付近のピークの振幅の值を各減 肉率についてまとめた結果を示している．Fig. 8 は減肉率が 増大するにつれて振幅が減少していく傾向が確認できた.ま た， $8.02 \times 10^{-9} \mathrm{sec}$ 付近についても確認してみたところ Fig. 8 と同様に減肉率が増大するにつれて振幅が減少していく傾 向が確認できた，従って，振幅の変化により減肉量を定量評 価することが可能であるとわかった．

\section{5. 結言}

本研究でマイクロ波の時間領域測定を行うことにより, 配 管のセンサ一側端部と減肉ジョイント側端部による反射を 確認することができた。本研究の結果より，マイクロ波信号 の反射の位置を定量的に評価することが可能であり，減肉量 に依存して, 減肉による反射波の測定感度が变化することが わかった。

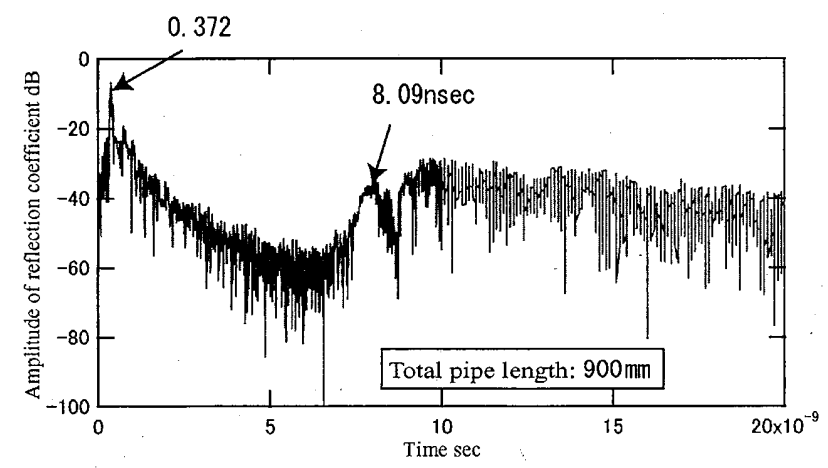

Fig. 4. Relationship between the amplitude of reflection coefficient and the time without a wall thinning joint and with a cap.

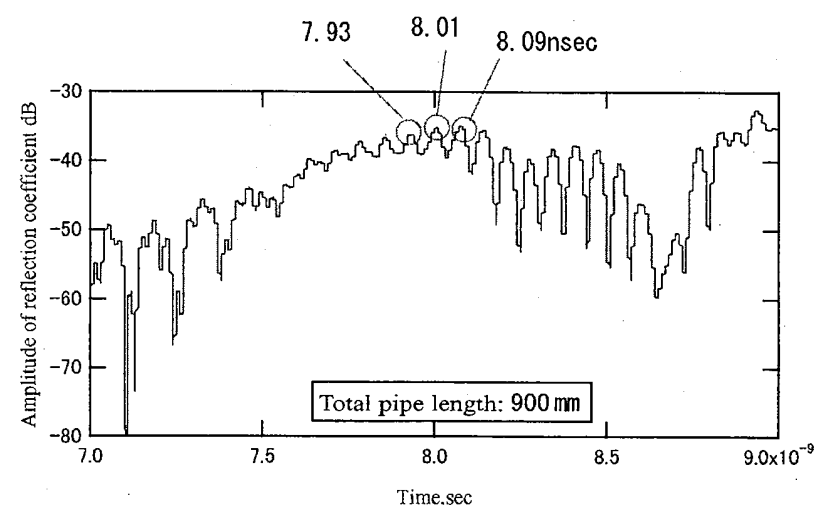

Fig. 5. Relationship between the amplitude of reflection coefficient and the time without a wall thinning joint and with a cap.

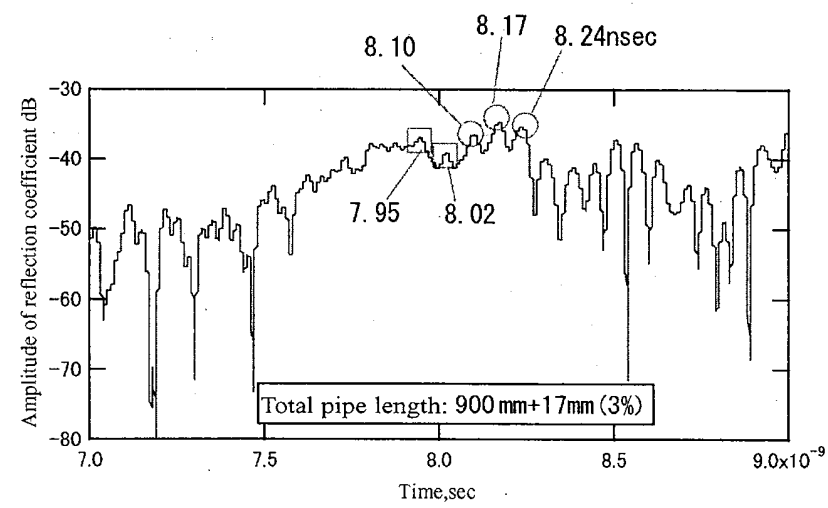

Fig. 6. Relationship between the amplitude of reflection coefficient and the time with $3 \%$ wall thinning joint and a cap.

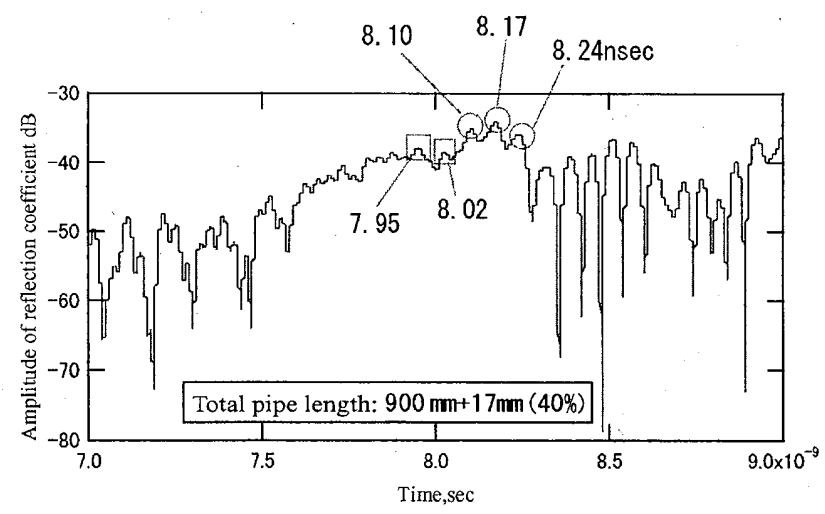

Fig. 7. Relationship between the amplitude of reflection coefficient and the time with $40 \%$ wall thinning joint and a cap.

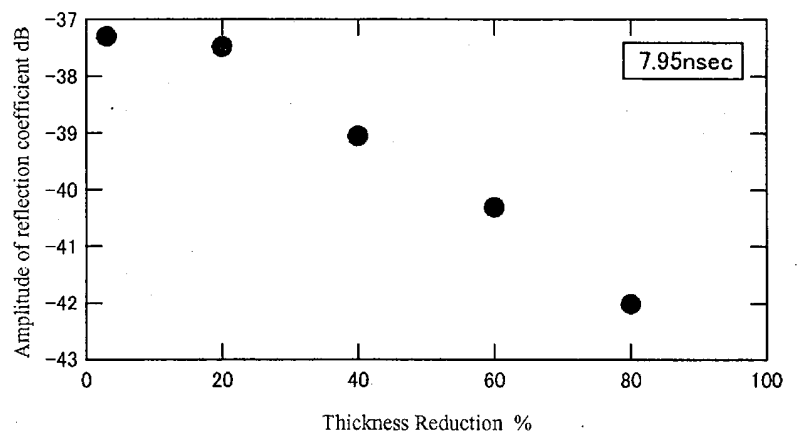

Fig. 8. Relationship between the amplitude of reflection coefficient and the rate of wall thinning. 